\title{
ASSESSMENT OF THE POPULATION EXPOSED TO ROAD TRAFFIC GENERATED NOISE. CASE STUDY: VASLUI TOWN, ROMANIA
}

DOI: http://dx.doi.org/10.18509/GBP.2019.71

UDC: 504.6:534.322.3]:656.2(498)

\author{
Ionuț Şorea \\ Cristian Constantin Stoleriu \\ Adrian Ursu \\ Andrei Urzica \\ Alexandru Ioan Cuza University of Iasi, Faculty of Geography and Geology, \\ Department of Geography, Iasi, Romania
}

\begin{abstract}
According to the Directive 2002/49/EC of the European Parliament and Council of 25 June 2002 relating to the assessment and management of environmental noise, a road traffic noise evaluation should end with an estimation of the exposed population. Based on this, further actions can be implemented in order to diminish the effect the environmental noise has on people within urban areas. The road traffic generated noise is one of the four main noise sources that are currently being under study; the others being the rail network, aviation and industrial areas. The current paper estimates the population exposure to the road traffic noise in an area comprising $9.87 \%$ of the total population of Vaslui town, North-Eastern Romania. The methodology followed in the first place a pattern for the noise levels generation. In order to accomplish this, a spatial database was created including the buildings and the road network of the study area. These features were assigned specific attributes being mandatory for the current study, like population size per building, building types, traffic volume etc. The noise simulation was then performed by the opeNoise plugin of QGIS Brighton 2.6.1. The result was a grid of points with different noise levels for two noise indexes: $\mathrm{L}_{\text {day-evening-night }}$ and $\mathrm{L}_{\text {night }}$. After the grid interpolation, the noise layers were used to calculate the impacted population size, implementing a method arisen from the European Commission recommendations.
\end{abstract}

Keywords: population exposure, road traffic noise, acoustic noise modeling, Vaslui town

\section{INTRODUCTION}

Among the environmental noise sources, one can encounter the road traffic inside the urban areas and outside, on main roads connecting the cities of a country, the rail network (trains and tramways), the industrial areas close to populated environments, and the airport runways. Out of these noise sources, the urban areas are highly impacted by the road traffic environmental noise, and at a lower level by the other sources [1].

The law that integrates the noise modeling and population exposure assessment for the urban municipalities in Romania is the Government Decision no. 321/2005 [2]. In addition to this, further Ministerial Orders were issued in order to create the basis for a better decision making process. The final results concerning the population exposure to environmental noise are also presented to the European Commission according to the Directive 2002/49/EC of the European Parliament and Council of 25 June 2002 relating to the assessment and management of environmental noise [3]. 
The population exposure assessment is being conducted based on a noise modeling for different noise sources. In the case of road traffic noise for the study area, this process brings about noise maps created to showcase the noise level distribution (over 5 decibels A-weighted intervals, abbreviated as $5 \mathrm{~dB}(\mathrm{~A})$ ) for two main indexes ( $\mathrm{L}_{\text {day-evening-night }}$ and $\mathrm{L}_{\text {night }}$ ), as a result of using the French NMPB-Routes-96 computation. A further validation is likely to be performed in order to increase the accuracy of the noise modeling. The validation is done through in-field measurements of the road traffic noise. For the current study, no validation was conducted.

The current paper is concerned with the modeling and assessment of the road traffic generated noise for Vaslui town, an urban municipality situated in the North-Eastern Romania. The study area consists of the main road network within the municipality limits, as follows: Calugareni St. and Traian St. in the West, Stefan cel Mare St. in the Central part connected to Decebal St. in the North and Republicii Blvd. in the South, and Decebal St. and an extension of Stefan cel Mare St. in the East and South-East.

The road traffic noise levels were calculated for a buffer of $50 \mathrm{~m}$ along the road network described above (Figure 1). The urban streets chosen as part of this study are diverse traffic type wise. Thus, the studied road network comprises ring roads carrying heavy traffic, main streets inside the urban framework, but smaller streets used to connect the main ones as well. The study area also comprises noise-sensitive institutions, like educational institutions.

Out of the total population of Vaslui town of 97,067 inhabitants (according to the 2011 Population and Housing Census [4]), the study area incorporates 9.87\%, meaning 9,585 inhabitants.

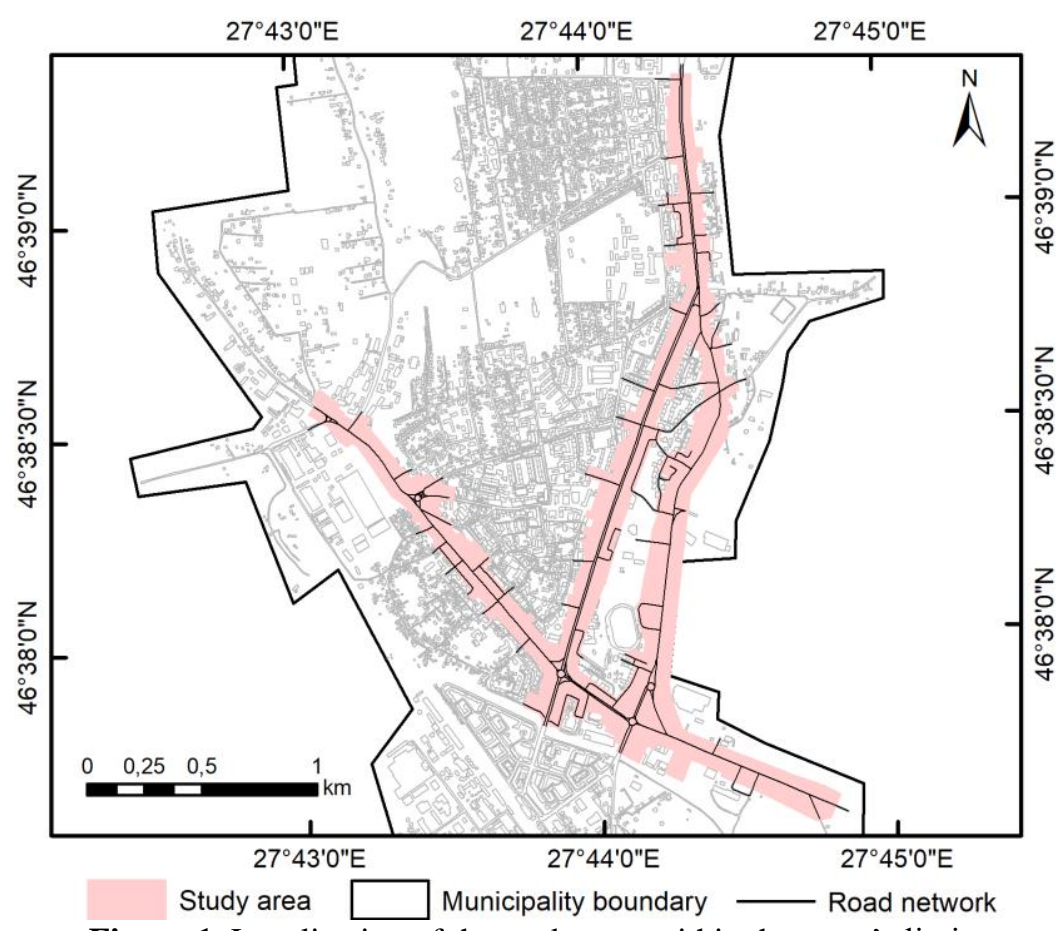

Figure 1. Localization of the study area within the town's limits

The factors that influence the noise propagation and are actually taken into consideration in the current paper are mainly of meteorological descend. Thus, the temperature is part of the computation method, influencing the noise level distribution in the way that lower the temperature, higher the noise generated by vehicles as the noise is more easily 
propagated through air [5-7]. The relative humidity also has an impact on the noise generation. There is a direct dependency between the air relative humidity and the noise level [5].

The software used to generate the noise maps is being unable to integrate the vegetation and ground effects, as they can absorb or reflect the noise [8].

It is to be noticed that no road traffic noise study was yet conducted on the road traffic of Vaslui town.

\section{METHODOLOGY}

The input data (Figure 2) is represented by buildings, as both noise receivers and obstacles to noise propagation, and road network, as noise source. The buildings layer included information regarding the population size per building which was later used to estimate the population exposure to over the limit noise levels. It also included the building type according to the following classification: residential, special use (schools, hospitals - as noise sensitive buildings) and other use (non-residential). The layer geometry is based on an orthophotography of the study area, while the population size was obtained through field observations.
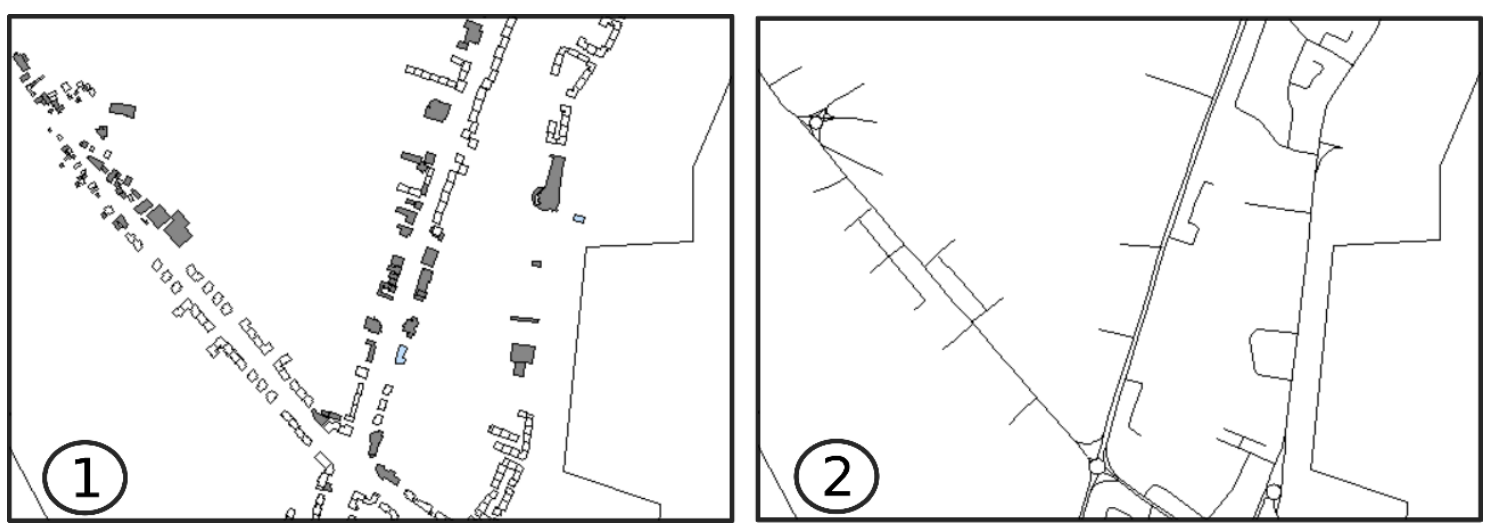

Figure 2. The layers used as input data for noise modeling (1 - buildings, 2 - road network)

The road network layer was digitized as polylines using an orthophotograph as well. The streets with a width bigger than $15 \mathrm{~m}$ were chosen to be represented as double line, while the others as simple line (according to Ministerial Order no. 1,830/2007 [9]). As main noise sources within the study area, the noise modeling is mainly concerned with the acquisition of good traffic data in the first place.

Table 1. Time periods used by the computation method

\begin{tabular}{cc}
\hline Index & Time period \\
\hline Lday & $7 \mathrm{am}-7 \mathrm{pm}$ \\
Levening & $7 \mathrm{pm}-11 \mathrm{pm}$ \\
Lnight & $11 \mathrm{pm}-7 \mathrm{am}$ \\
\hline \multicolumn{2}{c}{ source: Ministerial Order no. 678/1344/915/1397/2006 }
\end{tabular}

The traffic data used in the current study was obtained mainly through field observations or using the recommendations found in the National Legislation. For instance, the traffic volume was assigned to the road network layer by using the number of vehicles collected for two main roads (Traian St. and Stefan cel Mare St. - the sector between 'Crucea Garii' in the South and the junction with Decebal St. in the North) and the information provided in Tool 2.5 and Tool 4.5 of Ministerial Order no. 678/1344/915/1397/2006. These data 
was later extrapolated to the rest of the road network by using a street categorization: main roads, connecting roads and roads within residential area. The road network was also assigned information regarding the time period (Table 1) and the vehicle types (with a net load higher or lower than 3.5 tonne).

The vehicle speed values were assigned according to the limits per street type found in the National Legislation, so that no field measurement was done [1]. The longitudinal profiles (slope in opeNoise) were assigned as being either flat, down or up, according to a slope map of the area. The traffic flow type and the road surface, information required by software, was set to 'non-differentiated pulsed' and 'smooth' respectively.

The software used to model the noise levels for Vaslui town was QGIS Brighton 2.6.1. and opeNoise plugin, integrative part of the latest, while the noise calculation method was the French national computation method 'NMPB-Routes-96 (SETRA-CERTU-LCPCCSTB)', also described in the Directive 2002/49/EC. The noise levels were generated for a grid of points of $5 \mathrm{~m} \times 5 \mathrm{~m}$ dimension, for two noise indexes. These are $\mathrm{L}_{\mathrm{den}}$ for the road traffic noise assessment over a full-day time period and $\mathrm{L}_{\text {night }}$ to assess the noise during the $11 \mathrm{pm}-7$ am night period. The formula used to calculate $L_{d e n}$ is the following:

$$
\text { Lden }=10 \cdot \lg \frac{1}{24}\left(12 \cdot 10^{\frac{\text { Lday }}{10}}++4 \cdot 10^{\frac{\text { Levening }+5}{10}}+8 \cdot 10^{\frac{\text { Lnight }+10}{10}}\right),
$$

where $\mathrm{L}_{\mathrm{day}}$, $\mathrm{L}_{\text {evening }}$ and $\mathrm{L}_{\text {night }}$ represent the noise levels calculated accroding to NMPBRoutes-96 computation method for the time periods described in Table 1.

The computation method also required data as the research ray (set to $50 \mathrm{~m}$ ), temperature mean $\left(25^{\circ} \mathrm{C}\right)$ and relative humidity $(50 \%)$ to be specificed [10].

The grid of points, having assigned the noise levels for Lden and Lnight, is further interpolated using the Inverse Distance Weighting (IDW) method with a power of 2. The IDW noise data interpolation method is yet to be unanimously used, but it was being used in the current paper as many articles agreed upon it $[1,11,12]$.

The final noise maps are representations of noise levels distributed as $5 \mathrm{~dB}(\mathrm{~A})$ intervals and saved as raster. The estimation of the population size exposed to over the limit noise levels is being performed according to the recommendations of the Ministerial Order no. 678/1344/915/1397/2006 (chapters 3.1.6 to 3.1.8) [13]. The noise limits for $L_{d e n}$ is 70 $\mathrm{dB}(\mathrm{A})$, while for $\mathrm{L}_{\text {night }}$ is $60 \mathrm{~dB}(\mathrm{~A})$ (according to Ministerial Order no. $152 / 558 / 1119 / 532 / 2008$ [14]).

\section{RESULTS AND DISCUSSIONS}

The noise levels distribution is shown as contour lines on noise maps created by interpolating the values for $\mathrm{L}_{\mathrm{den}}$ and $\mathrm{L}_{\text {night }}$ indexes (Figure 3).

For $\mathrm{L}_{\mathrm{den}}$ index, the street that generates the loudest noise over its entire length is Decebal St., in the Eastern part of the study area. This street is characterized by values higher than $75 \mathrm{~dB}(\mathrm{~A})$. The reason behind this is the type of vehicles the street carries. Being a ring road, the heavy traffic is diverted here so that the inner roads lack it. Another element of the road network whose population situated close to it is exposed to high noise levels is represented by the junction areas ( $\mathrm{L}_{\mathrm{den}}$ values up to $80 \mathrm{~dB}(\mathrm{~A})$ and above). 


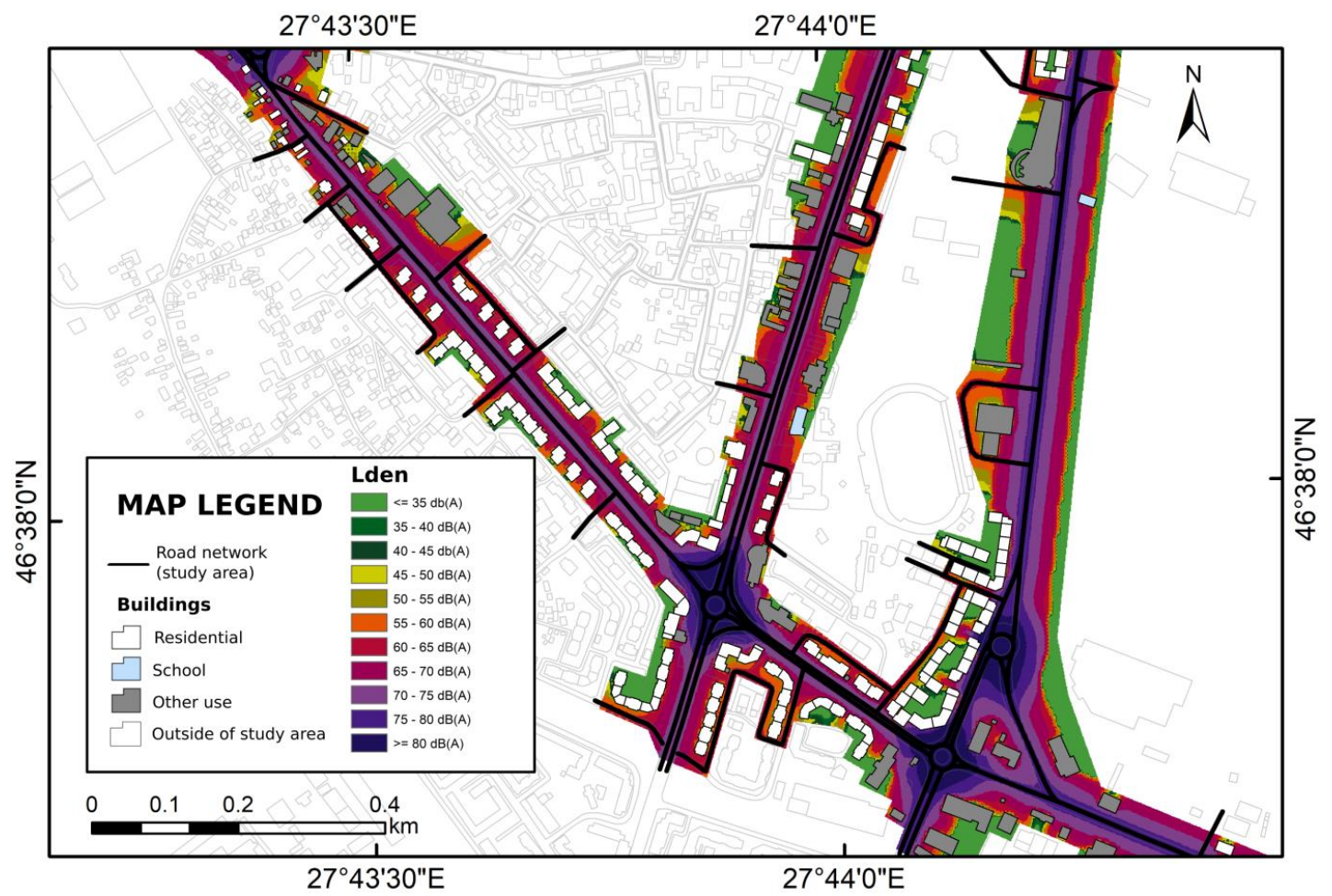

Figure 3. Detail on the southern part of the study area $\left(L_{\text {den }}\right.$ noise map)

The same situation is encountered in the case of $\mathrm{L}_{\text {night }}$ noise levels distribution, the differences lying in the fact that the $\mathrm{L}_{\text {night }}$ values are up to 5-10 $\mathrm{dB}(\mathrm{A})$ lower than those of $\mathrm{L}_{\mathrm{den}}$ index.

When studying the exposure to road traffic noise, one should consider the noise sensitive institutions as well (e.g. hospital, educational institutions). Although they are not residential buildings, the activities that occur inside them can be highly disturbed by the environmental noise. Within the study area, there are no sanitary institutions, but a total of seven educational buildings, as follows: three secondary schools, two high schools, one school gymnasium and one annex. They are exposed to $L_{\text {den }}$ values of up to 70-75 $\mathrm{dB}(\mathrm{A})$.

Table 2. Population exposure assessment to $\mathrm{L}_{\mathrm{den}}$ and $\mathrm{L}_{\text {night }}$ noise indexes for the study area

\begin{tabular}{lcccccccccccc}
\hline \multicolumn{11}{c}{ Noise level $(\mathbf{d B}(\mathbf{A}))$} \\
\hline & $<\mathbf{3 5}$ & $\mathbf{3 5 - 3 9}$ & $\mathbf{4 0 - 4 4}$ & $\mathbf{4 5 - 4 9}$ & $\mathbf{5 0 - 5 4}$ & $\mathbf{5 5 - 5 9}$ & $\mathbf{6 0 - 6 4}$ & $\mathbf{6 5 - 6 9}$ & $\mathbf{7 0 - 7 4}$ & $\mathbf{7 5 - 7 9}$ & $\boldsymbol{>}=\mathbf{8 0}$ \\
\hline Size of population exposed to Lden & 1839 & 184 & 321 & 474 & 726 & 1521 & 1883 & 1539 & 910 & 168 & 20 \\
\hline Size of population exposed to Lnight & 2308 & 446 & 664 & 1276 & 1567 & 1982 & 977 & 334 & 31 & 0 & 0 \\
\hline
\end{tabular}

Nevertheless, the main exposure evaluation is being performed for the residential buildings. For the current study area, out of the total population of 9,585 inhabitants, $11.45 \%$ are exposed to $\mathrm{L}_{\mathrm{den}}$ values higher than the limit of $70 \mathrm{~dB}(\mathrm{~A})$, while $14 \%$ are exposed to $\mathrm{L}_{\text {night }}$ values higher than $60 \mathrm{~dB}(\mathrm{~A})\left(\mathrm{L}_{\text {night }}\right.$ value limit). This means that almost 1,100 inhabitants can be affected by high noise levels over a full-day time period. During the night, there are approximately 1,345 inhabitants exposed to over the limit values. All the detailed results are shown in Table 2, and as histograms in Figure 4. 


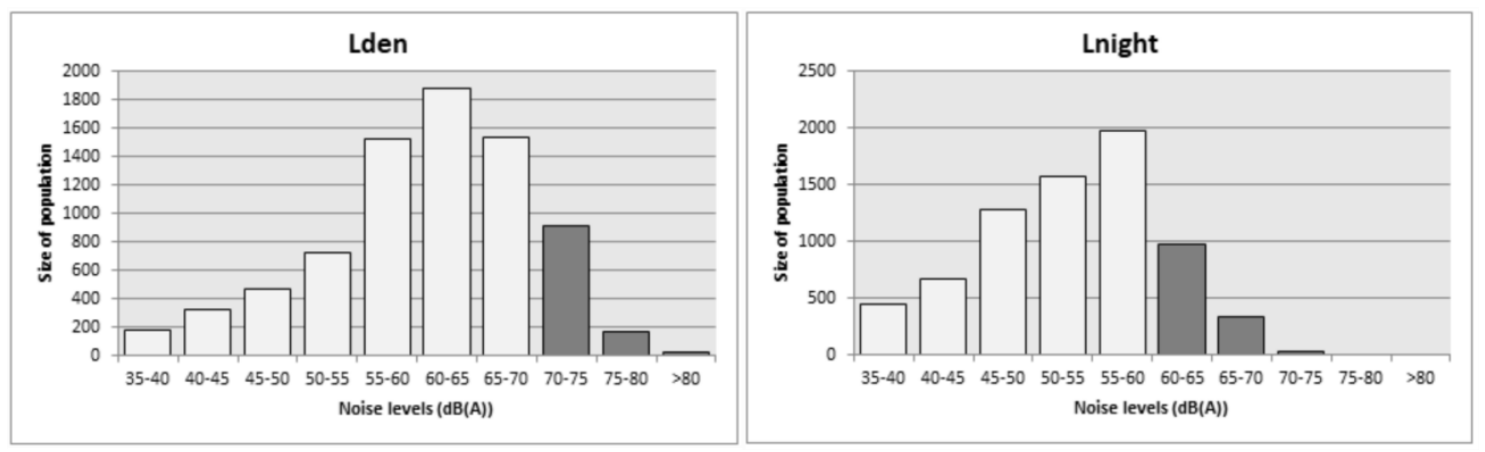

Figure 4. Population size distribution on noise intervals for $\mathrm{L}_{\mathrm{den}}$ and $\mathrm{L}_{\text {night }}$

\section{CONCLUSIONS}

Knowing the size of the population affected by high noise levels plays an important role in the decision making process lead by the local authorities. As stated in the Directive 2002/49/EC of the European Parliament and Council of 25 June 2002 relating to the assessment and management of environmental noise, a noise modeling should bring about the number of people exposed to environmental noise. In the case of the current paper, the noise source was the road traffic inside urban areas.

The population assessment represented the last step of the noise modeling and was done by taking into consideration the number of people per building in the areas exposed to road traffic noise. The current study revealed the differences that appear when the assessment is performed on two different types of urban streets. A first type was being represented by the inner area roads, characterized by lower values when compared to a second type of streets: ring roads. The latest carry the heavy traffic of the town and thus are expected to have higher values of the noise levels. The junctions inside the urban area have an important influence on the final exposure evaluation as well. These areas are characterized by noise levels $10 \mathrm{~dB}(\mathrm{~A})$ higher in average than the surroundings. The junctions also have a high population density, making them one of the hot-spots of exposure to road traffic noise.

The final results are only based on the French NMPB-Routes-96 computation method and are expected to be further validated through in-field measurements. Nevertheless, the current study represented one of the first assessments of population exposure to road traffic noise ever to be conducted in the case of Vaslui town.

\section{REFERENCES}

[1] Murphy, E., Rice, H., Meskell, C. (2006), Environmental noise prediction, noise mapping and GIS integration: the case of inner Dublin, Ireland. East-European Acoustical Association. 8th International Transport Noise and Vibration Symposium, St. Petersburg

[2] *** (2005), Hotărârea de Guvern nr. 321 din 14.04.2005 (M.O. nr. 19/10.01.2008) privind evaluarea şi gestionarea zgomotului ambiant, reactualizată prin Hotărârea de Guvern nr. 1260 (M.O. nr. 15/19.01.2013) (in Romanian)

[3] *** (2002), Directive 2002/49/EC of the European Parliament and Council of 25 June 2002 relating to the assessment and management of environmental noise

[4] *** (2011) Population and Housing Census (Recensământul populației și al locuințelor), Institutul Naţional de Statistică, București (in Romanian)

[5] Subramani, T., Kavitha, M., Sivaraj, K.P. (2012), Modeling Of Traffic Noise Pollution. International Journal of Engineering Research and Applications, 2(3), 3175-3182 
[6] Bendtsen, H., Lu, Q., Kohler, E. (2009), Temperature influence on road traffic noise, Californian OBSI measurement study, Report 169. Road Directorate, Danish Road Institute

[7] Mioduszewski, P., Taryma, S., Wozniak, R. (2014), Temperature influence on type/road noise of selected tyres. Inter-noise. Melbourne, Australia

[8] Yang, H.S. (2013), Outdoor noise control by natural/sustainable materials in urban areas. The University of Sheffield, School of Architecture (PhD thesis)

[9] *** (2007), Ordinul Ministrului nr. 1830/2007 pentru aprobarea „Ghidului privind realizarea, analizarea și evaluarea hărților strategice de zgomot” (in Romanian)

[10] Larion, D. (2004), Clima municipiului Vaslui, Ed. Terra Nostra, Iasi (in Romanian)

[11] Farcaș, F., Sivertun, A. (2012). Road Traffic Noise: GIS Tools for Noise Mapping and a Case Study for Skane Region. The International Archives of the Photogrammetry, Remote Sensing and spatian Information Sciences, 34 (XXX)

[12] Murat, O., Ebru, S.E. (2016). Determination of traffic noise pollution of the city of Tekirdag. Journal of Environmental Protection and Ecology, 17(4), 1276-1284

[13] *** (2006), Ordinul Ministrului M.M.G.A./M.T.C.T./M.S./M.A.I. nr. 678/1344/915/1397/2006 și publicat în Monitorul Oficial nr. 730/2006 pentru aprobarea „Ghidului privind metodele interimare de calcul al indicatorilor de zgomot pentru zgomotul produs de activitățile din zonele industriale, de traficul rutier, feroviar și aerian din vecinătatea aeroporturilor" (in Romanian)

[14] *** (2008), Ordinul Ministrului nr. 152/558/532/2008 pentru aprobarea „Ghidului privind adoptarea valorilor limită și a modului de aplicare a acestora atunci când se elebaorează planurile de acțiune pentru indicatoii Lzsn și Lnoapte în cazul zgomotului produs de traficul rutier pe drumurile principale şi în aglomerări, traficul feroviar pe căile ferate principale şi în aglomerări, traficul aerian pe aeroporturile mari şi/sau urbane şi pentru zgomotul produs în zonele de aglomerări unde se desfaşoară activităţi industriale prevazute în anexa nr. 1 la O.U.G nr. 152/2005 privind prevenirea și controlul integrat al poluării” aprobată cu modificări și completări prin Legea nr. 84/2006 (in Romanian) 